P-ISSN: 2541-6960; E-ISSN: 2549-8754

Yupa: Historical Studies Journal

Vol. 3 No. 1, 2019 (38-48)

http://jurnal.fkip.unmul.ac.id/index.php/yupa

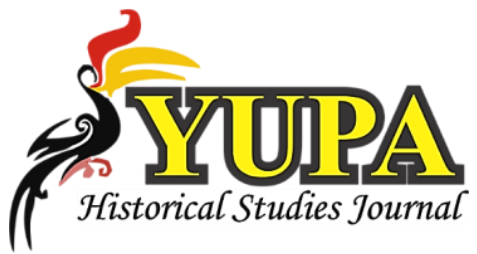

\title{
The Existence of First Indigenous Scouting Javaansche Padvinders Organisatie in Mangkunegaran
}

\author{
Renny Pujiartati \\ Universitas Sebelas Maret, Surakarta, indonesia \\ rennypujiartati31@student.uns.ac.id
}

\begin{tabular}{ccc}
\hline Received & Accepted & Published \\
$13 / 06 / 2020$ & $27 / 06 / 2020$ & $30 / 06 / 2020$ \\
\hline
\end{tabular}

\begin{abstract}
Scouting progress occurs when the national movement of Indonesia is progressive. Scouting is used as a forum to improve the noble character, skills, personality, and sense of nationality among Indonesian youth. Besides, scouting is a medium to strengthen a national awareness of Indonesian youth. The first indigenous scouting was Javaansche Padvinders Organisatie or abbreviated as JPO. This organization was founded by Mangkunegoro VII. The establishment of the JPO was followed by the establishment of other indigenous scouting organizations. This study aims to determine the background, development, and role of the first indigenous scouting of Javaansche Padvinders Organisatie (JPO) in Mangkunegaran.
\end{abstract}

Keywords: indigenous scouting, Javaansche Padvinders Organisatie (JPO), Mangkunegaran.

\begin{abstract}
Abstrak Proses munculnya kepramukaan seiring dengan munculnya berbagai gerakan progresif di Indonesia. Kepramukaan digunakan sebagai forum untuk meningkatkan karakter mulia, keterampilan, kepribadian dan rasa kebangsaan di kalangan pemuda Indonesia. Selain itu, Kepramukaan adalah media untuk memperkuat kesadaran Nasional tentang pemuda Indonesia. Kepramukaan pribumi pertama adalah Javaansche Padvinder Organisatie atau disingkat JPO. Organisasi ini didirikan oleh Mangkunegoro VII. Pendirian JPO diikuti dengan pendirian organisasi Kepramukaan pribumi lainnya. Penelitian ini bertujuan untuk menentukan latar belakang, pengembangan dan peran pemanduan pribumi pertama Javaansche Padvinder Organisatie (JPO) di Mangkunegaran.
\end{abstract}

Kata kunci: kepramukaan pribumi, Javaansche Padvinders Organisatie (JPO), Mangkunegaran 


\section{INTRODUCTION}

Scouting was a media of youth activities existing in Indonesia since the beginning of the 20th century (Utomo, 1995). The establishment and development of indigenous scouting movements in Indonesia can't be separated from the state of Indonesian society in the colonial era which is underdeveloped and experiencing discrimination in all fields. However, the colonial system with all its political forms, especially since the ethical politics of the beginning of the 20th century had led to a modernization process in areas such as transmigration, irrigation, education, and so on. Kartodirdjo, Poesponegoro, and Notosusanto mentioned that ethical politics changed the view in colonial politics that assumed that Indonesia was not a lucrative area, but it needed to be developed so that it could be fulfilled and enhanced the culture of its indigenous people (Kartodirdjo, 1975).

The scouting movement started in England in 1907 which was initiated by Lord Baden Powell. In 1908, Baden Powell wrote the book Scouting for Boys. Then, the book spread throughout the European continent to the colonies and resulted in greater scouting. Scouting in Indonesia was first born in Jakarta in 1912 entitle Nederlance Padvinders Organisatie abbreviated as NPO. This organization was founded by John Smith on the recommendation of a wand association in the Netherlands (Utomo, 1995). Within a short period, some Dutch padvinders organization was established in Indonesia, finally, on September 4th, 1914 united in NIPV (Nederlands Indische Padvinders Vereeniging). NIPV had exactly promises and laws like the Dutch scout, which read with Trouw aan de Koningin, meaning faithful to the Queen of the Netherlands. The promise was gradually felt by Indonesian youth as a thorn in the meat for the Indonesian nation (Sumarmo, 1974). The youth began to appear a sense of nationalism wanted to establish an indigenous scouting organization that has a pledge of allegiance to the nationality.

Every scouting organization generally has its style in terms of the factors behind its establishment, the conducted activities, its development, and the roles. JPO was the first scouting organization established by indigenous in 1916. This organization was founded on Mangkunegoro VII. The establishment of this JPO then pioneered the establishment of other indigenous scouting organizations. In 1942 Japan entered Indonesia, dissolving all national movement organizations and all indigenous organizations, the JPO and all youth organizations were also dissolved (Citrosoma, 1994).

\section{METHOD}

This study applies the historical method, which is the process of critically testing and analyzing the past tapes and relics, then reconstructed based on obtained data from several kinds of literature, such as libraries and archives. The historical method has several steps, they are: (1) heuristics, ie collecting traces of the past, (2) criticism, ie investigating the traces of the past both 
the form and its content, (3) the interpretation, ie determining the interconnected meaning of fact -facts obtained, (4) historiography, ie conveying syntheses obtained in the form of writing and stories. Sources of data used are primary data sources (1) Kepandoean magazine published by the board of Javaansche Padvinders Organisatie Mangkunegaran; (2) Soerya Magazine No. 8 the year 1939; (3) Leader Magazine JPO No. 2 the year 1938; (4) Minangkabau Tejepenganipoen Padvinders (1920), in the Bundel Masalah Mangkunegaran and Krida Muda; (5) Statuten Javaansche Padvinders-Organisatie (JPO) in Mangkunegaran Surakarta at Bundel Masalah Mangkunegaran and Krida Muda Secondary sources are relevant books, internet, and journals to the research theme.

Sources of data conducted both primary and secondary in this study are written data so that the data collection techniques use literature study techniques. Library study is a study investigating to collect data or material contained in books, magazines, documents, and newspapers. Data collection is conducted by reading and recording the primary sources that discuss scouting in general and especially about Javaansche Padvinders Organisatie in Mangkunegaran from magazines, archives, and books.

\section{RESULT AND DISCUSSION \\ Background of JPO Establishment}

The external factors of the establishment of JPO could be seen from the development of the scouting movement before the establishment of JPO. The scouting movement was firstly established in England in 1907 initiated by Baden Powell (Sunardi, 2013). After Baden Powell founded scouting, the scouting education system then spread to several countries including to Nederland and then expanded by the Dutch to the colonies of Indonesia. The scouting organization was firstly developed in Jakarta in 1912 entitle Nederlansche Padvinders Organisatie, abbreviated as NPO. NPO was founded by John Smith on the recommendation of witch associations in the Netherlands so that the establishment of scouting in Indonesia was originally Neerlando centric (Utomo, 1995). On September 4th, 1914 the scouting societies were united in a media called Neederlands Indische Padvinders Vereeniging (NIPV). NIPV was the only scouting organization recognized by the De Neederland Indische Regering government as a scouting organization in the Neederlandsch Indie (Sumarmo, 1974)

The scouting movement rapidly grew in Indonesia, after the establishment of NIPV. In addition to NIPV in Indonesia, there were also other scouting organizations whose members were still limited to an only certain society, for example in European schools (Pringgodigdo, 1994). In addition to its exclusive nature, NIPV had promises and laws exactly like the Dutch scouts. The promise of NIPV was the word trouw aan de koningin which means faithful to the Queen of the Netherlands. The promise was gradually felt like a thorn in the flesh by the youths who began to 
flare their nationalism up, resulting in many scouting organizations that escaped from NIPV. The words of promise loyal to the Queen of the Netherlands then replaced with trouw aan mijn Land en Volk which meant faithful to the country and the nation (nationalism) (Sumarmo, 1974).

Indonesian people faced scouting could be used as a medium to improve noble character, skills, and personality as well as cultivate leadership talent. All of these things were useful to foster a sense of nationality among youth (Utomo, 1995). In reaction to the development of scouts in Indonesia, then there were efforts from the inhabitants of Bumi Putera to establish their scouting organization.

The first established indigenous scouting organization was Javaansche Padvinders Organisatie or abbreviated to JPO in September 1916 in the capital city of Mangkunegaran or Solo. The establishment of a scouting organization in Mangkunegaran, couldn't be separated from the role of Mangkunegoro VII as a Javanese noble who became an activist of Budi Utomo (Pringgodigdo, 1994). The establishment of JPO followed by the establishment of other indigenous scouting organizations. The objective of Mangkunegoro VII to establish JPO was as a forum for the young generations to involve and prepare them to participate in the current movement of the nation towards the independence of Indonesia (Widada, 2008). Ahmad Dahlan, the founder of the Muhammadiyah Movement was deeply impressed by what he saw about JPO in Mangkunegaran and decided to bring scouting to his organization (Semedi, 2011:p. 38)

The other established indigenous scouting organizations were Hizbul Wathan, founded by Muhammadiyah and Nationale Padvinderij by Budi Utomo. Jong Java Padvinderi (JJP) founded by Jong Java. Scouting organization Teruna Kembang was founded by Prince Surjosubroto in Kasunanan Surakarta. In 1923 also established the Nationale Padvinders Organisatie (NPO) of Indonesian Youth led by Usman. Jong Sumatranen Bond established Pandu Pemuda Sumatra, while Sarekat Islam established Wira Tamtama with its leader A. Zarkasih.

Since the end of the Diponegoro War in 1830, the power, authority, influence, prestige, and privileges of kings in the Vorstenlanden region were increasingly restricted and reduced. Supervision over the Vorstenlanden area was also increasingly tightened (Suhartono, 1991). The intervention by the colonial government made the kings of the Vorstenlanden region hurt and unimpeded in running the government in their kingdom. It is also felt by Mangkunegoro VII, especially after being crowned as king in Mangkunegaran swapraja, Mangkunegoro VII had to release all his positions in the stewardship of Budi Utomo. The Dutch colonial government continually sought to limit and supervise and always suspect all attitudes, actions, and activities related to the movement of nationhood (Larson, 1990).

Evaluating from the socio-political conditions that occurred in Mangkunegaran swapraja in the early days of Mangkunegoro VII, it seemed that the main objective of Mangkunegoro VII to establish JPO is for political purposes. JPO was used to demonstrate and affirm the nationalism, 
leadership, power, influence, pioneering, and self-existence of Mangkunegaran in the presence of the Dutch colonial government and other Javanese kings, especially Paku Buwana X. The establishment of JPO in swapraja Mangkunegaran had shown the pioneering and leadership of Mangkunegoro VII as king of Java as the first one who establishes an indigenous scouting organization. The success of Mangkunegoro VII in well set up a scouting organization, then followed by other national figures, Kasunanan Surakarta also didn't worry behind by establishing a scouting organization named Teruna Kembang led by Prince Surjosubroto (Utomo, 1995).

Kawula swapraja Mangkunegaran consisted of the king kawula namely the indigenous and foreign people consisting of Eastern Foreign, Europe, and Indo, so that Kawula swapraja Mangkunegaran was a plural society. In the kejawen (ancient) areas of Vorstenlanden such as swapraja Mangkunegaran, Javanese were the majority social group (Pringgokusumo, 1987). This Javanese was the king kawula, as the main supporter of the political system in the form of the Javanese kingdom, following the owned and embraced Javanese traditional culture and value system.

Ahead of the establishment of the JPO, education for indigenous communities in swapraja Mangkunegaran was the slowest development if compared with the development of education in other Vorstenlanden areas (Singgih, 1944). Mangkunegoro VII as a modern and Westerneducated monarch argued that the presence of JPO would be of great benefit to the people of Mangkunegaran. The formation of JPO was one way to promote social life, especially education outside the family and school or nonformal education, kawula Mangkunegaran has been under time development (Yosowidagdo, 1987).

\section{Development of Javaansche Padvinders Organisatie in Mangkunegaran}

At the beginning of its establishment, JPOs were difficult to recruit members. This happens because scouting activities had not been so popular among the Mangkunegaran community. Scouting organizations and their activities were still new and still difficult to understand the form of Western cultural influences. Also, the indigenous society of swapraja Mangkunegaran still thinks that JPO was an elite and exclusive organization whose membership was only specific to the rich people of indigenous communities in swapraja Mangkunegaran.

JPO also had other obstacles such as the skills and knowledge of the JPO leiders in the field of scouting was still very minimal. The number of JPO leiders was also very little, while the management generally didn't have the skills as leaders. If the leiders in the moving area, then the group of scouting who left the area would be disbanded. The maintenance of the board continued to be done to advance the JPO, the result is 1923 the number of branches of JPO increased into five branches namely Solo and several municipalities in the district of Mangkunegaran City, including Tasikmadu, Colomadu, Baturetno, and Karanganyar. 
In this period, JPO was can handle the faced constraints in the previous period. In 1931 the number of branches of JPO increased, JPO had 6 branches namely Solo, Wonogiri, Baturetna, Karanganyar, Tasikmadu, and Colomadu. Each branch had its board. This board consisted of administrators who run organizations and technical commissioners who take care of scouting (Wasino, 2008). JPO's progress could also be seen from the increase of branches. In 1934 the JPO had 10 branches consisting of Solo, Wonogiri, Batoeretno, Karanganyar, Tasikmadu, Colomadu, Jatisrono, Slogohimo, Karangpandan, and Ngoentoronadi. While the areas Kebakkramat, Ngargojoso, Wuryantoro, Ngadirjo, Ngargoyoso, and Pratimantoro just planned to join a branch of JPO. By the end of 1935, JPO had 2,378 members and administrators. The JPO managers work on several ways to progress the JPO by cultivating funds and administering the ed administration. The JPO organizers always hold courses for the leader to improve leader capacity (Kepandoean No.3, 1936). JPO progressed and developed, in 1937 had 28 branches and the number of its members reached 6000 people (Citrosoma, 1994).

JPO was actively engaged with other scouting organizations such as Jong Java Padvinderij by holding congresses held in Solo in 1926, 1927, 1928, and 1929. Congress was also participated by Pandu Indonesia (Programma van het Jong Java Padvinderscongres, 1928). In 1926 JPO attended a meeting in Yogyakarta hosted by NIPV. The meeting was attended by Hizbul Wathon, Nationale Padvinderij, Indonesische Nationale Padvinders, and Nationale Padvinders Organisatie who later refused to join NIPV (Semedi, 2011).

In June 1937 JPO followed jamboree padvinder held in the Netherlands by sending representatives of 6 people (Soerya Magazine No. 8, 1939). The participation of JPO in the world jamboree had proved that JPO didn't only exist in the swapraja Mangkunegaran area, but also internationally. The period 1939 to 1942 was the period of JPO abandonment. One of the factors causing the decline of JPO was the decision of JPO who joined NIPV. Many members of the JPO did not agree with the decision, then left the JPO. Another factor was the internal problems that occur between JPO and Krida Muda. Both of these organizations continued to compete in terms of winning influence in the swapraja Mangkunegaran.

In the early of 1942, Japan began to colonize Indonesia. On March 31st, 1942 Colonel Nakayama (head of the general section of the interim Japanese military occupation government) as the representative of Major General Harada (Head of the Japanese military occupation government in Batavia) visited Mangkunegaran palace. The visit of Colonel Nakayama as well as an official declared that Mangkunegaran directly under the power of the Japanese military occupation government which was centered in Batavia (Pringgokusumo, 1989). The Japanese military occupation government then dissolved all national movement organizations and all indigenous associations, so the JPO and all youth and indigenous organizations in Mangkunegaran were also dissolved. On the orders of the Japanese military government, in 1943 Mangkunegoro 
VII established Barisan Gyo Tai and also Java Renggo Seinendan to replace the swapraja Mangkunegaran youth organizations (Citorsoma, 1994).

\section{Role of Javaansche Padvinders Organisatie in Mangkunegaran (1916-1942)}

JPO as a scouting organization that grows and develops during the social life Mangkunegaran community performed several functions and social activities that benefit its members and also the subjects Mangkunegaran. JPO acts as a media and means for Mangkunegaran subjects who were members in preparing their physical and spiritual to face the increasingly complex and modern social life in the future according to the time's development (Kepandoen No. 2, 1936).

The social activities undertaken by JPO was one form of propaganda contained in the promises of scouts as well as the statutes of the JPO. In the statutes of the JPO it stated that to realize its objectives, JPO applied several steps, one of them was to instill a sense of responsibility, love for each other, and also being helpful (Statuten Javaansche Padvinders Organisatie, 1932). These steps were also aligned with the guiding promises that JPO members had to keep. The scout promises were that he had to be ready to sacrifice, love to work, and not disappoint (Kepandoean No. 1, 1936).

JPO often helped the general public such as building mosques, schools, bridges, orphanages, and so forth. In 1936 the JPO formed Troep Bahoe Sasra or the Tentara Sambatan, whom a squad of an army of leavers, leiders, and leidsters who served the swapraja Mangkunegaran government in health, hygiene and environmental beauty (Kepandoean No. 9, 1936). In 1937 the JPO also established a death auxiliary association called Tresno Soedoro or T. S. JPO and the association also comprised of scouts, leiders, and leidsters (Kepandoean No. 5 and 6 , 1938). Some examples of the above JPO social activities had shown that as long as the management of JPO did a role in the social field.

The JPO statutes stated that JPO didn't do the political activities. However, in its development, JPO conducted political activities on the orders of Mangkunegoro VII as a protector of JPO. JPO conducted political activities jointly with youth organizations in Mangkunegaran such as the Legiun Mangkunegaran and Pekempalan Kawoela Mangkoe Negaran abbreviated by PKMN and other indigenous scouting organizations. Political activities aimed to prove to the others that the swapraja Mangkunegaran has great physical strength, was well organized and modern, and reliable as volunteers in carrying out the particular interests and purposes of Mangkunegoro VII as well as the Mangkunegaran self-government. Activities in the political field serve to show that Mangkunegoro VII has great power, authority, influence, and power in politics. The outsiders are the Dutch colonial government and the swapraja Kasunanan, especially to the kings of the swapraja Kasunanan. 
Since the establishment of JPO, it has always been involved in various ceremonies and celebrations of the Mangkunegaran palace together with the Legiun Mangkunegaran and other Mangkunegaran youth organizations which were subsidized by the swapraja Mangkunegaran government. These organizations must prove the various ceremonies and celebrations of the palace by displaying various interesting attractions. This activity is politically intended to prove to outsiders the loyalty and obedience of the Kawula Mangkunegaran, including the learned classes, to Mangkunegoro VII.

Cooperation was conducted between JPO and other indigenous scouting organizations. This cooperation activity is scouting and non-scouting. Non-scouting activities undertaken by JPO and other indigenous organizations were by way of obstructing and opposing any NIPV effort to incorporate indigenous scouting organizations with NIPV. The indigenous scouting organizations did not want to join the NIPV, because if they joined the NIPV, they had to be loyal, obedient, and willing to cooperate with the Dutch colonial government. Enterprises didn't want to join the NIPV indicates that indigenous scouting organizations, especially JPOs, do not want to be controlled by the power of the Dutch colonial government. Indigenous scout organizations often hold congresses. In the congress discussed the political steps they will take to face the NIPV and also the Dutch colonial government. The congresses attended by the JPO were Jong Java Padvinderij congress in Solo in 1926, 1927, 1928, and 1929. The congress was also followed by other indigenous scouts such as Pandu Indonesia (Programma van het Jong Java Padvinders congress, 1928). In 1926 JPO attended a meeting in Yogyakarta hosted by NIPV. The meeting was attended by Hizbul Wathon, Nationale Padvinderij, Indonesische Nationale Padvinders, and Nationale Padvinders Organisatie who later refused to join NIPV (Semedi, 2011).

On June 5th, 1932 in Surakarta was established a political organization called Perkumpulan Kawula Surakarta (Surakarta Youth Association) abbreviated with the MCC under the leadership of Mr. Singgih (Larson, 1990). The PKS supported by the swapraja Mangkunegaran tried to expand its influence in the rural areas of the swapraja Mangkunegaran. To anticipate the influence of the MCC in the Swapraja Mangkunegaran region, Mangkunegoro VII established a counter-political organization in rural areas under the name PKMN. JPO was assigned by Mangkunegoro VII to assist PKMN activities. On November 11th,1934 PKMN established a youth organization called Krida Muda. Since 1934 Mangkunegoro VII and the swapraja Mangkunegaran government have ordered JPO, Krida Muda, and PKMN to stem the influence of the PKS. Besides, to improve the quality and quantity of Legiun Mangkunegaran which was the physical strength and pride of Mangkunegaran swapraja, Mangkunegoro VII, and swapraja Mangkunegaran government recruit members of Mangkunegaran youth organizations to become members of Mangkunegaran Legion (Kepandoen No. 4, 1936, Pringgodigdo, 1994). 
Mangkunegoro VII's attention in the field of education was enormous, not limited only to the people in swapraja Mangkunegaran but also to the people of the Indonesian population in general (Citrosoma, 1994). This can be seen from some of Mangkunegoro VII's policies in education such as establishing a school called Siswo, creating a special committee to eradicate illiteracy in Mangkunegaran swapraja, establishing youth organizations such as Krida Muda and JPO. Mangkunegara was very concerned about spiritual and physical education for his society.

Kepandoen magazine volume 1 year 1936 mentioned that JPO as a place of education, where scouting provides opportunities to young children. These young people are expected to have a healthy body, possessing good knowledge and character. The main objective of the JPO listed in its articles of association was to educate and direct children, especially in terms of personality and gesture to become useful and valuable residents (Wasino, 2008).

The JPO Pandu Rule contained 13 articles, a promise that JPO members had to keep. This rule was the main guide of the implemented education system by JPO. Those promises are the behavioral guidelines that should be executed by the JPO members. By carrying out the main guidelines in the guiding legislation it was expected that JPO members would have a positive attitude of life. A positive attitude of life here was a scout deeply expected to always be confident, have a soul knight, quick in making decisions, trustworthy, simple and also understated, love of his homeland, and so forth. Thus, it can be concluded that the members of JPO had been guided to have great social awareness, noble character, good attitude, even political education in organizational life and state. JPO activities were essentially educational in nature to build the character of its members.

Javaansche Padvinders Organisatie taught typical Javanese court art of Mangkunegaran palace to its members and generally to Mangkunegaran, especially in rural areas of swapraja Mangkunegaran (Kepandoean No. 10, 1936). JPO taught macapat songs to its members. The taught macapat songs to contain values that must be owned by a scout.

In addition to the typical Javanese arts of Mangkunegaran, JPO also introduced and popularized Western art to its members. Western art, such as music art with modern musical instruments, modern drama, and so forth. JPO emphasized that the members were educated in terms of music both Javanese music and other music to cultivate a sense of refinement as well as hearts when JPO hold activities such as training, camperen enz, adventure, and so forth.

JPO also taught its members to love culture like Batik. Kepandoean Magazine No. 3 \& 4 mentions that a scout is expected to make batik, especially for the female scout. Batik has its advantages because by batik someone is taught to always concentrate. Batik also teaches patience and meticulousness (1938). Activities that had been done by JPO to introduce the arts to its members showed that JPO also had a role in the field of art. 


\section{CONCLUSION}

Javaansche Padvinders Organisatie was the first established indigenous scouting organization. The establishment of JPO was inseparable from the role of Mangkunegoro VII as the king of Swapraja Mangkunegaran who the activist of Budi Utomo. The background of the establishment of JPO was influenced by two factors of external and internal factors. External factors came from the development of world scouting founded by Baden Powell in England, while the internal factors derived from the conditions of Swapraja Mangkunegaran consisting of sociopolitical and socio-cultural conditions.

The development of JPO is divided into 3 periods. The period 1916-1923 was an early period, so the JPO was still having trouble recruiting members. The 1924-1938 period was a period of progress in the JPO, in 1937 the JPO had 28 branches with 6.000 members. The period 1929-1942 was a period of JPO decline which was later dissolved by the Japanese in 1942.

The role of JPO in the social aspect is as a media and means in preparing the body and spiritual members to face social life in the future. Politically, the JPO conducted political activities to show that Mangkunegoro VII has great power, authority, influence, and power in political life. The role of JPO in culture is education and art. JPO is used as a forum to educate and direct children, especially in terms of the formation of personality and gesture to become a useful and valuable resident. In the field of art, JPO actively teaches the typical Javanese arts of Mangkunegaran Palace to its members and generally to the people of Mangkunegaran.

\section{REFERENCES}

Citrosoma, A. S. 1994. Oesaha dan Djasa Sri Mangkunegoro VII Terhadap Pendidikan dan Pengajaran. Artikel tidak diterbitkan, No. 416 Perpustakaan Rekso Pustoko Mangkunegaran.

Kartodirdjo, S., Poesponegoro, M.J., \& Notosusanto ， N. 1975. Sejarah Nasional Indonesia V. Jakarta: Departemen Pendidikan dan Kebudayaan.

Kepandoean, No. 1, Tahun I, Januari 1936.

Kepandoean, No. 10, Tahun I, Oktober 1936

Kepandoean, No. 2, Tahun I, Februari 1936

Kepandoean, No. 3 dan 4, Tahun III, Maret-April 1938

Kepandoean, No. 4, Tahun I, Maret 1936

Kepandoean, No. 5 dan 6, Tahun III, Mei-Juni 1938

Kepandoean, No. 9, Tahun I, September 1936

Larson, Goerge D. 1990. Masa Menjelang Revolusi, Keraton dan Kehidupan Politik di Surakarta, 1912-1942. Terj. Lapian. Yogyakarta: Gadjah Mada University Press. 
Pringgodigdo, A. K. 1994. Sejarah Pergerakan Rakyat Indonesia. Jakarta: Dian Rakyat.

Pringgokusumo, Husodo. 1989. Kedudukan Pangeran Mangkunegoro dalam Struktur Politik yang Terpecah Belah di Jawa Tengah. Surakarta: Artikel tidak diterbitakan, No. 1424 Perpustakaan Reksa Pustoko Mangkunegaran.

Programma van het Jong-Java Padvinderscongres Gehouden te Solo den 24-28 Juni 1928, No. 61 Perpustakaan Rekso Pustoko Mangkunegaran.

Semedi, Pujo. 2011. Padvinders, Pandu, Pramuka: Youth and State in the 20th Century Indonesia (Versi elerktonik). Afrika Development, 36 (3 \& 4), 19 - 38. Diperoleh 01 Maret 2014, dari http://www.ajol.info/index.php/ad/article/view/74113/64773.

Singgih, R. P. 1986. Partini: Tulisan Kehidupan Seorang Putri Mangkunegaran. Terj. Margareth M. Alibasah. Jakarta: PT. Djambatan.

Soerya, No. 8, Tahun 1939

Statuten Javaansche Padvinders Organisatie (JPO), dalam Bundel Masalah JPO Mangkunegaran dan Krida Muda, No. P 180 Arsip Rekso Pustoko Mangkunegaran.

Suhartono. 1991. Apanage dan Bekel, Perubahan Sosial di Padesaan Surakarta (1830-1920). Yogyakarta: PT. Tiara Wacana Yogya.

Sumarmo, dkk. 1974). 45 Tahun Sumpah Pemuda. Jakarta: Yayasan Gedung- Gedung Bersejarah Surakarta.

Sunardi, Andri Bob. 2013. Boyman: Ragam Latih Pramuka. Bandung: Nusa Muda.

Utomo, C. B. 1995. Dinamika Pergerakan Kebangsaan Indonesia: dari Kebangkitan hingga Kemerdekaan. Semarang: IKIP Semarang Press.

Wasino. (2008). Kapitalisme Bumi Putra Perubahan Masyarakat Mangkunegaran. Yogyakarta: LKiS.

Widada. (2008). Mengenang B. R. M Soerya Soeparto: Bergerak dan Melangkah Maju untuk Bangsanya. Surakarta: Yayasan Mangadeg.

Yosowidagdo, Raden Ngabei. (1987). Bocah Mangkunegaran. Terj. Tidak diterbitkan oleh Srikayati, No. 871 Perpustakaan Rekso Pustoko Mangkunegaran. 